University of Nebraska - Lincoln

DigitalCommons@University of Nebraska - Lincoln

USDA National Wildlife Research Center - Staff Publications
U.S. Department of Agriculture: Animal and Plant Health Inspection Service

2009

\title{
Avian Use of Harvested Crop Fields in North Dakota During Spring Migration
}

Alegra M. Galle

Department of Biological Sciences, North Dakota State University

George M. Linz

USDA/APHIS/WS National Wildlife Research Center, george_m_linz@yahoo.com

H. Jeffrey Homan

USDA-APHIS-WS

William J. Bleier

Department of Biological Sciences, North Dakota State University

Follow this and additional works at: https://digitalcommons.unl.edu/icwdm_usdanwrc

Part of the Environmental Sciences Commons

Galle, Alegra M.; Linz, George M.; Homan, H. Jeffrey; and Bleier, William J., "Avian Use of Harvested Crop Fields in North Dakota During Spring Migration" (2009). USDA National Wildlife Research Center - Staff Publications. 921.

https://digitalcommons.unl.edu/icwdm_usdanwrc/921

This Article is brought to you for free and open access by the U.S. Department of Agriculture: Animal and Plant Health Inspection Service at DigitalCommons@University of Nebraska - Lincoln. It has been accepted for inclusion in USDA National Wildlife Research Center - Staff Publications by an authorized administrator of DigitalCommons@University of Nebraska - Lincoln. 
Western North American Naturalist 69(4), (C) 2009, pp. 491-500

\title{
AVIAN USE OF HARVESTED CROP FIELDS IN NORTH DAKOTA DURING SPRING MIGRATION
}

\author{
Alegra M. Galle1,2, George M. Linz ${ }^{3}$, H. Jeffrey Homan ${ }^{4}$, and William J. Bleier ${ }^{1}$
}

\begin{abstract}
Broad-spectrum herbicide applications and improved harvesting efficiency of crops have reduced the availability of weed seeds and waste grains for game and nongame wildlife. Over the last decade, corn and soybean plantings have steadily increased in the Prairie Pothole Region (PPR) of North Dakota, while sunflower plantings have declined. The PPR is an important corridor for migratory birds, and changes in food availabilities at stopover habitats may affect how food resources are used. In early spring 2003 and 2004, we compared bird use of harvested fields of sunflower, soybeans, small grains, and corn in the PPR of North Dakota. Across both years and all crop types, we observed 20,400 birds comprising 29 species. Flocks of Lapland Longspurs (Calcarius lapponicus) and Horned Larks (Eremophila alpestris) and flocks of Red-winged Blackbirds (Agelaius phoeniceus) made up 60\% and 15\%, respectively, of the bird counts. We found that species richness and bird densities were higher in harvested sunflower fields and cornfields than in harvested small-grain and soybean fields, with soybean fields harboring the fewest species and lowest bird density. Blackbird densities tended to be lower in fields tilled after fall harvest than in fields not tilled. These results suggest that some granivorous bird populations in the Northern Great Plains could be positively affected by planting of row crops with postharvest vertical structure (e.g., sunflower, corn) and use of no-till land management practices.
\end{abstract}

Key words: birds, untilled land, sunflower, corn, soybeans, small grains, weeds, North Dakota, Prairie Pothole Region.

Most avian ecology studies are conducted during the breeding season, resulting in a lack of understanding of bird-habitat relationships at other times of the year, especially during migration and winter (Moore et al. 1995, Hutto 1998, Igl and Ballard 1999, Hutto 2000, Peterjohn 2003, Tankersley and Orvis 2003, Holmes 2007). Knowledge of the types of habitats and food resources used by migratory bird species at stopover sites is still rudimentary (Russell et al. 1994, Hutto 2000, Petit 2000, Schaub and Jenni 2001, Sawin et al. 2006). Stopover times can last anywhere from a few hours to several days, depending on the energetic condition of the migrant and the quality of the stopover habitat (Moore et al. 1995). Lack of suitable stopover habitats could exacerbate mortality risks by slowing the pace of migration, and a slower migration might be a factor for increased mortality (Cody 1985, Schaub and Jenni 2001, Kelly et al. 2002, Rodewald and Brittingham 2002). Moreover, competition for foods at reduced numbers of stopover sites along a migration route could affect the ability of migrants to refuel (Cody 1985, Kelly et al. 2002).
Competition for limited food resources at other times of the year, besides during the migration period, can also have a negative impact on food availability at a stopover site. For example, during winter months, nonmigratory birds require high-energy foods to survive in northern temperate zones, which are characterized by snowcover, cold temperatures, and long nights (Best et al. 1998, Pravosudov et al. 1999). A change in available food resources caused by changes in agricultural practices may in turn affect the distribution and numbers of winter seed-eating bird species, both among and within fields (Robinson and Sutherland 1999, Perkins et al. 2000, Moorcroft et al. 2002). The increased foraging pressure on high-quality sites during winter could result in lower-quality stopover sites for the spring migrants.

Broad-spectrum herbicide applications and improved harvesting efficiency have reduced the availability of weed seeds and waste grains for game and nongame wildlife that use harvested fields as food resources. Over the last decade in the Prairie Pothole Region (PPR) of North Dakota, corn and soybean plantings have

\footnotetext{
${ }^{1}$ Department of Biological Sciences, North Dakota State University, Fargo, ND 58105.

2Present address: USDA-APHIS, Idaho-WS, 9134 West Black Eagle Dr., Boise, ID 83709.

${ }^{3}$ Corresponding author. USDA-APHIS-WS, National Wildlife Research Center, 2110 Miriam Circle, Bismarck, ND 58501. E-mail george.m.linz@aphis.usda.gov

${ }^{4}$ USDA-APHIS-WS, National Wildlife Research Center, 2110 Miriam Circle, Suite B, Bismarck, ND 58501.
} 
steadily increased. During the same time, sunflower plantings have declined. This region is an important bird migration corridor (Stewart 1975). Changes in the agricultural landscape of the PPR and reduced plant diversity in crop fields could severely diminish foraging opportunities for migratory and nonmigratory birds (Watkinson et al. 2000, Krapu et al. 2004). In this paper, we contribute data on bird use of 2 crops with substantial postharvest vertical structure (sunflower and corn) and 2 crops without postharvest vertical structure (wheat and soybean) during spring migration in a critical migratory corridor, the PPR of North Dakota.

In spring 2003 and 2004, we identified and quantified birds in each of these agricultural habitats. Our aim was to provide information that might lead to modified management guidelines and recommendations for private and government land managers charged with providing or enhancing site quality of stopover habitats. Efforts to preserve breeding grounds will fall short of conservation goals if quality stopover habitats en route are not provided (Moore et al. 1995, Holmes 2007).

\section{Methods}

\section{Study Area}

Our study was conducted in the Southern Drift Plains (SDP) of North Dakota-one of the physiographic subregions of the PPR (Stewart 1975). This region is characterized by level to gently sloping landscapes and numerous natural-basin wetlands that were created by advancing and retreating glaciers during the late Pleistocene epoch. Growers in our 14 study counties planted an average of 765,351 ha of small grains (mainly barley, oats, and wheat), 330,522 ha of corn, 967,974 ha of beans (largely soybeans), and 184,979 ha of sunflower across study years (NDASS 2005).

\section{Site Selection and Seasonal Timing}

Compared to other crops, little data have been published on bird use of sunflower, particularly during spring migration. Thus, we chose to devote $50 \%$ of our resources to surveying sunflower fields and the other $50 \%$ to surveying small-grain, corn, and bean fields. In early spring 2003, we scouted 240 randomly selected legal quarter sections (each 65 ha) in the SDP and found that 37 quarter sections contained harvested sunflower; we randomly chose 30 of these units for our sample. For comparison, we also randomly selected another 30 quarter sections from the same 240 and found that 13 contained small-grain fields (largely wheat and barley), 5 contained cornfields, and 12 contained bean fields (soybeans and edible beans). Similarly, in spring 2004, we scouted the same 240 quarter sections and found that 22 contained harvested sunflower. We used all 22 and randomly chose another 32 quarter sections from the pool of 240 and found them to contain 16 small-grain fields, 6 cornfields, and 10 soybean fields. To maintain sample independence, adjacent quarter sections were not chosen.

We intended to count birds in each field 2 times per year between $22 \mathrm{March}$ and 30 April 2003 and between 21 March and 2 May 2004. Prior to the second counts in 2003 and 2004, farmers tilled $38 \%$ and $56 \%$ of the sample fields, respectively, and thus no second counts were done for these fields. The counts were initiated when areal snow coverage was $\leq 50 \%$. To reduce travel time, we grouped all fields into 4-field count units and randomly selected, without replacement, one unit per morning for counts.

\section{Bird Density}

We adhered to the bird-counting techniques established by Stewart and Kantrud (1972) and later followed by Igl and Johnson (1997). Stewart and Kantrud's (1972) methodology was designed to obtain a complete count of all birds on the study site. Upon arriving at the selected site, we scanned the field for large groups of birds (e.g., blackbirds, larks, and longspurs), wary birds (e.g., pheasants), and birds of prey (Best et al. 1998). Two trained biologists started at opposite sides of the field; each walked line transects that were $100 \mathrm{~m}$ apart and that ran perpendicular to the shortest axis of the field. Line transects started 50 $\mathrm{m}$ from the field edge (Stewart and Kantrud 1972, Igl and Johnson 1997). We identified and counted birds within $50 \mathrm{~m}$ of either side of transect lines. Birds that flew over the fields without landing were not counted. Deviation from the transect line was allowed for bird identification. Observers took care to minimize double counting of birds by noting the locations of birds that were flushed to other parts of the field (Best et al. 1998). Walking speed on transects was approximately $1.0-2.0 \mathrm{~km} \cdot \mathrm{h}^{-1}$ 
(Hanowski et al. 1990). Counts were initiated at sunrise, and all 4 fields were completed approximately 5 hours later. Counts were not conducted during steady precipitation or winds $>24 \mathrm{~km} \cdot \mathrm{h}^{-1}$.

\section{Seed Density}

We collected seed samples along 4 randomly selected transects. Sampling occurred at 400-m intervals along each transect, starting from a random point between 1 and $400 \mathrm{~m}$ from the edge of the field. At each sampling point, we placed a $20 \times 20$-cm sampling frame on the ground and the top 1-cm layer of soil was collected with a garden trowel. We also collected seeds from standing vegetation within the frame. Soil samples were placed in small paper bags (labeled by site with sample number) and frozen (to prevent seed germination and molding) until seeds were sorted (Klute and Robel 1997). Each sample was emptied onto paper and allowed to dry for one week in a cool, dry, dark room. Dried samples were sifted through mesh sieves of successively smaller sizes (6.7-0.84-mm openings), and debris and large clumps of soil were discarded so that only seeds and fine vegetative parts were left. We separated the organic material from the fines using an aqueous solution of sodium hexametaphosphate, sodium bicarbonate, and magnesium sulphate (Malone 1967). The floating organic material was decanted from the solution, run through a $0.5-\mathrm{mm}$ sieve, and rinsed to remove foam and minute soil particles. We air-dried the sample, sorted the seeds of sunflower, corn, small grain, beans, and weeds, and weighed the seeds to the nearest $0.01 \mathrm{~g}$.

\section{Surrounding Habitat}

We obtained photographs of our study area from the USDA Natural Resources Conservation Service (NRCS) Data Gateway (NRCS 2004) as mosaics of digital orthophoto quarter quads. These were imported into ArcInfo v8.3 GIS. An 804-m buffer was placed around the borders of the quarter sections containing each study field. A nonmapping technique was used to estimate the area of the habitats available within the entire buffer area (Marcum and Loftsgaarden 1980). Habitat classes included wetland (temporary to intermittently exposed), grass (hay, alfalfa, pasture, and Conservation Reserve Program lands), tree (shelterbelts, woodlots, and riparian forests), small grain (oats, barley, rye, and various types of wheat), sunflower (oil and non-oil varieties), bean (soybeans and edible beans), corn (silage and grain), and other (roads, buildings, developed areas, lakes, ponds, and large rivers). We divided the frequency of each class by the total number of specified points $(n)$ within the buffer area to get proportionate coverage of each habitat class, which was then converted to hectares. Means and standard errors were calculated for each year for different habitat types within the perimeter of the polygon surrounding each study field.

\section{Analysis}

We estimated seed densities by calculating the mass per volume of soil collected $(\mathrm{g} /[400$ $\left.\left.\mathrm{cm}^{2} \cdot 1 \mathrm{~cm}\right]\right)$. Logarithmic transformations (ln) were performed on seed-density data to adjust for departure from normality. Differences in seed densities between crops were examined using a one-way ANOVA. We used simple linear regression to determine if there was any relationship between seed densities and bird density across fields. Bird density was used as the response variable, while seed density was used as the explanatory variable.

Categories of "passerine," "Lapland Longspur/Horned Lark," and "blackbird" densities (birds $\cdot \mathrm{ha}^{-1}$ ) were used as indicators of habitat quality because they had high frequencies of occurrence in our counts and were abundant (see Table 1 for scientific names). Horned Larks and Lapland Longspurs (Calcarius lapponicus) were often seen in large mixed-species flocks, making it hard to distinguish between individual species (Beason 1995, Hussell and Montgomerie 2002). For each study field, total species richness per hectare was estimated for each count and mean richness per hectare compared across crop types. We used logarithmic transformations (ln) on bird-density data to adjust for departure from normality and then back-transformed by raising 10 to the power of the mean species richness per hectare, which can result in asymmetrical error bars. We used $t$ tests and analysis of variance (ANOVA) to assess the data. All statistical tests were conducted using an alpha of 0.05.

\section{REsults}

Areal coverage of sample fields was nearly identical between years, averaging $38 \mathrm{ha}\left(s_{\bar{x}}=\right.$ 
TABLe 1. Percentage of fields, across 2 counts, with avian species observed in harvested crop fields in the Southern Drift Plains, North Dakota, during 21 March-2 May in 2003 and 2004.

\begin{tabular}{|c|c|c|c|c|c|}
\hline Common name & Scientific name & $\begin{array}{l}\text { Sunflower } \\
(n=69)\end{array}$ & $\begin{array}{c}\text { Corn } \\
(n=20)\end{array}$ & $\begin{array}{l}\text { Small grain } \\
(n=52)\end{array}$ & $\begin{array}{l}\text { Soybean } \\
(n=34)\end{array}$ \\
\hline American Crowa & Corvus brachyrhynchos & 3 & 0 & 0 & 0 \\
\hline American Robin & Turdus migratorius & 16 & 15 & 4 & 18 \\
\hline American Tree Sparrow & Spizella arborea & 23 & 30 & 6 & 9 \\
\hline Brown-headed Cowbird & Molothrus ater & 4 & 5 & 4 & 3 \\
\hline Brewer's Blackbird & Euphagus cyanocephalus & 6 & 0 & 0 & 0 \\
\hline Canada Goose & Branta canadensis & 7 & 30 & 15 & 60 \\
\hline Common Grackle & Quiscalus quiscula & 7 & 15 & 6 & 3 \\
\hline Wilson's Snipe & Gallinago gallinago & 1 & 5 & 0 & 3 \\
\hline Dark-eyed Junco & Junco hyemalis & 13 & 10 & 0 & 6 \\
\hline Field Sparrowa & Spizella pusilla & 3 & 0 & 0 & 0 \\
\hline Horned Lark & Eremophila alpestris & 94 & 38 & 88 & 94 \\
\hline Lapland Longspur & Calcarius lapponicus & 42 & 14 & 25 & 21 \\
\hline Horned Lark/Lapland Longspurb & & 22 & 10 & 0 & 0 \\
\hline Killdeer & Charadrius vociferus & 49 & 24 & 36 & 54 \\
\hline House Sparrow & Passer domesticus & 0 & 5 & 2 & 0 \\
\hline Mallard & Anas platyrhynchos & 10 & 30 & 12 & 24 \\
\hline Mourning Dove & Zenaida macroura & 9 & 14 & 6 & 0 \\
\hline Northern Flicker & Colaptes auratus & 1 & 5 & 0 & 0 \\
\hline Northern Pintaila & Anas acuta & 1 & 0 & 0 & 0 \\
\hline Ring-necked Pheasant & Phasianus colchicus & 1 & 10 & 4 & 3 \\
\hline Rock Pigeon ${ }^{\mathrm{a}}$ & Columba livia & 1 & 0 & 0 & 0 \\
\hline Red-winged Blackbird & Agelaius phoeniceus & 62 & 55 & 25 & 15 \\
\hline Sandhill Crane & Grus canadensis & 0 & 0 & 2 & 0 \\
\hline Savannah Sparrow & Passerculus sandwichensis & 13 & 20 & 10 & 12 \\
\hline Snow Goose & Chen caerulescens & 0 & 5 & 2 & 0 \\
\hline Song Sparrow & Melospiza melodia & 20 & 25 & 14 & 6 \\
\hline Sharp-tailed Grouse & Tympanuchus phasianellus & 23 & 10 & 12 & 0 \\
\hline Vesper Sparrow & Pooecetes gramineus & 16 & 30 & 14 & 9 \\
\hline Western Meadowlark & Sturnella neglecta & 44 & 30 & 17 & 3 \\
\hline Yellow-headed Blackbird & Xanthocephalus xanthocephalus & 9 & 10 & 8 & 0 \\
\hline
\end{tabular}

aNot seen in 2004

bixed-species flock

1.6). Likewise, land use within $0.8 \mathrm{~km}$ of the study quarter sections was similar $(F$ range $0.24-3.38, P$ range $0.069-0.627)$ between years for 7 of 8 categories, averaging 55 ha $\left(s_{\bar{x}}=3.6\right)$ wetland, 127 ha $\left(s_{\bar{x}}=8.8\right)$ grass, 9 ha $\left(s_{\bar{x}}=\right.$ $0.9)$ trees, 133 ha $\left(s_{\bar{x}}=7.4\right)$ small grain, 120 ha $\left(s_{\bar{x}}=7.9\right)$ beans, 34 ha $\left(s_{\bar{x}}=4.5\right)$ corn, and 10 ha $\left(s_{\bar{x}}=1.4\right)$ other. Areal coverage of ripening sunflower was significantly less $(F=9.94, P=$ $0.002)$ in $2004\left(\bar{x}=23\right.$ ha, $\left.s_{\bar{x}}=3.3\right)$ than in $2003\left(\bar{x}=51\right.$ ha, $\left.s_{\bar{x}}=5.0\right)$.

In 2004, waste-seed densities did not differ across crops $(F=0.21, P=0.889)$, averaging $0.11 \mathrm{~g} / 400 \mathrm{~cm}^{3}\left(s_{\bar{x}}=0.02\right)$. During the first count, blackbird, Lapland Longspur/Horned Lark, and total passerine densities were not related to seed density ( $F$ range $0.06-0.62, P$ range $0.437-0.811)$. During the second count, blackbird density tended to be greater in fields with higher seed densities $(F=4.59, P$ $=0.052)$; whereas Lapland Longspur/Horned Lark density $(F=0.23, P=0.637)$ and total passerine density $(F=0.58, P=0.456)$ were similar across seed densities.

In 2003 and 2004, we identified 29 and 25 granivorous species, respectively (Table 1). We observed more species per hectare during the second count than we did during the first count $(F=17.15, P<0.001$; Table 2$)$. Overall, the number of species per hectare differed across crops $(F=4.03, P=0.008)$, with soybean hosting fewer species than sunflower, small grain, and corn. During the first count, the number of species differed among crops $(F=$ $3.05, P=0.032$ ), with sunflower hosting more species than did soybean. During the second count, the number of species across crops was not significantly different $(F=2.40, P=0.08)$.

Densities of blackbirds, Lapland Longspur /Horned Larks, and passerines were not different between years during the first counts ( $t$ range $0.78-1.00, P$ range $0.320-0.438$ ) or second counts $(t$ range $0.22-1.71, P$ range 0.094-0.827); therefore, bird densities were 


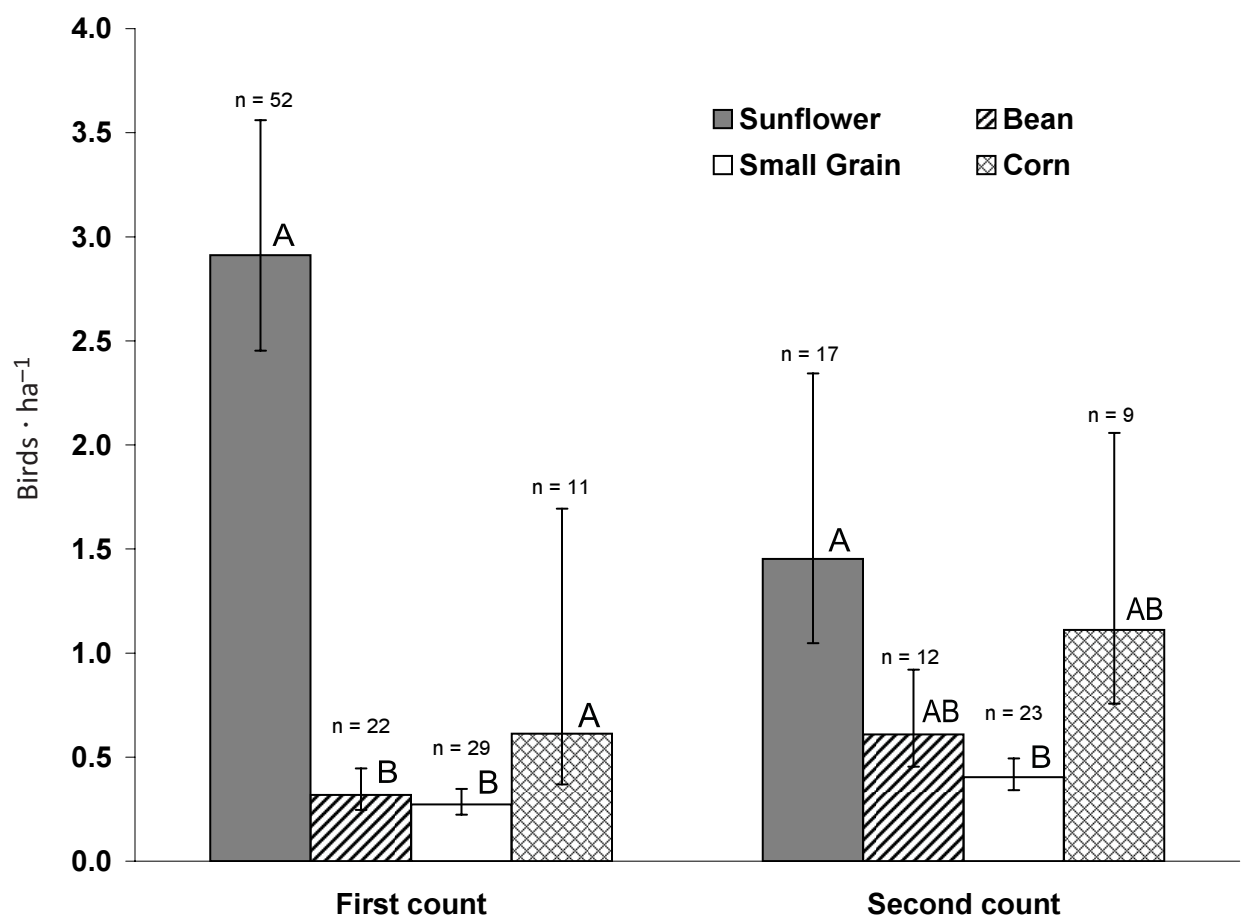

Fig. 1. Mean densities and associated standard errors of passerines (birds $\cdot \mathrm{ha}^{-1}$ ) in harvested sunflower, bean, small grain, and corn fields in the Southern Drift Plains, North Dakota, 2003 and 2004. Crops with different letters are significantly different at $\alpha=0.05$. Data were back-transformed from natural-log transformations by raising 10 to the power of the mean species per hectare.

TABLE 2. Mean number of avian species per hectare (standard error) in 4 harvested crops in the Southern Drift Plains, North Dakota, during spring 2003 and 2004. Crop types with different letters are significantly different at $\alpha=0.05$.

\begin{tabular}{lllll}
\hline Count period & \multicolumn{1}{c}{ Sunflower } & \multicolumn{1}{c}{ Bean } & \multicolumn{1}{c}{ Small grain } & \multicolumn{1}{c}{ Corn } \\
\hline 21 March-17 April & $0.13(0.01) \mathrm{A}$ & $0.07(0.02) \mathrm{B}$ & $0.09(0.02) \mathrm{AB}$ & $0.12(0.03) \mathrm{AB}$ \\
18 April-2 May & $0.22(0.04) \mathrm{A}$ & $0.07(<0.01) \mathrm{A}$ & $0.20(0.06) \mathrm{A}$ & $0.28(0.08) \mathrm{A}$ \\
\hline
\end{tabular}

pooled across years within the early and late counts for subsequent analyses.

Passerine densities differed $(F=14.99, P$ $<0.001)$ between the first count $\left(\bar{x}=1.27, s_{\bar{x}}\right.$ $=0.18)$ and the second count $\left(\bar{x}=0.41, s_{\bar{x}}=\right.$ 0.10). Within the first count, passerine densities were not statistically different between fields tilled after fall harvest and fields not tilled (untilled) $(F=0.52, P<0.604)$ but did differ between crops $(F=25.55, P<0.001)$, with more birds using sunflower and corn than birds using soybean and small grain (Fig. 1). During the second count, passerine densities differed among crops $(F=4.40, P=0.008)$, with sunflower hosting more birds than did small grain. Passerine densities were significantly higher $(F=3.04, P<0.004)$ in untilled fields $\left(\bar{x}=1.4, s_{\bar{x}}=0.55\right)$ than in tilled fields $\left(\bar{x}=0.61, s_{\bar{x}}=0.12\right)$.

Blackbirds constituted $16 \%$ of the total number of birds counted. Blackbird densities did not differ $(P=0.094)$ between the first and second counts, averaging 0.60 birds $\cdot \mathrm{ha}^{-1}$ $\left(s_{\bar{x}}=0.20\right)$. Blackbird densities were not significantly different $(F=0.61, P=0.614)$ among crops within the first count (Fig. 2). During the second count, blackbird densities differed among the 4 crops $(F=7.41, P<$ $0.001)$, with sunflower and cornfields hosting more birds than did soybean fields. During the first count, blackbird densities were significantly greater $(t=3.56, \mathrm{P}=<0.001)$ in untilled fields $\left(\bar{x}=0.55, s_{\bar{x}}=0.13\right)$ than in tilled fields $\left(\bar{x}=0.21, s_{\bar{x}}=0.12\right)$. 


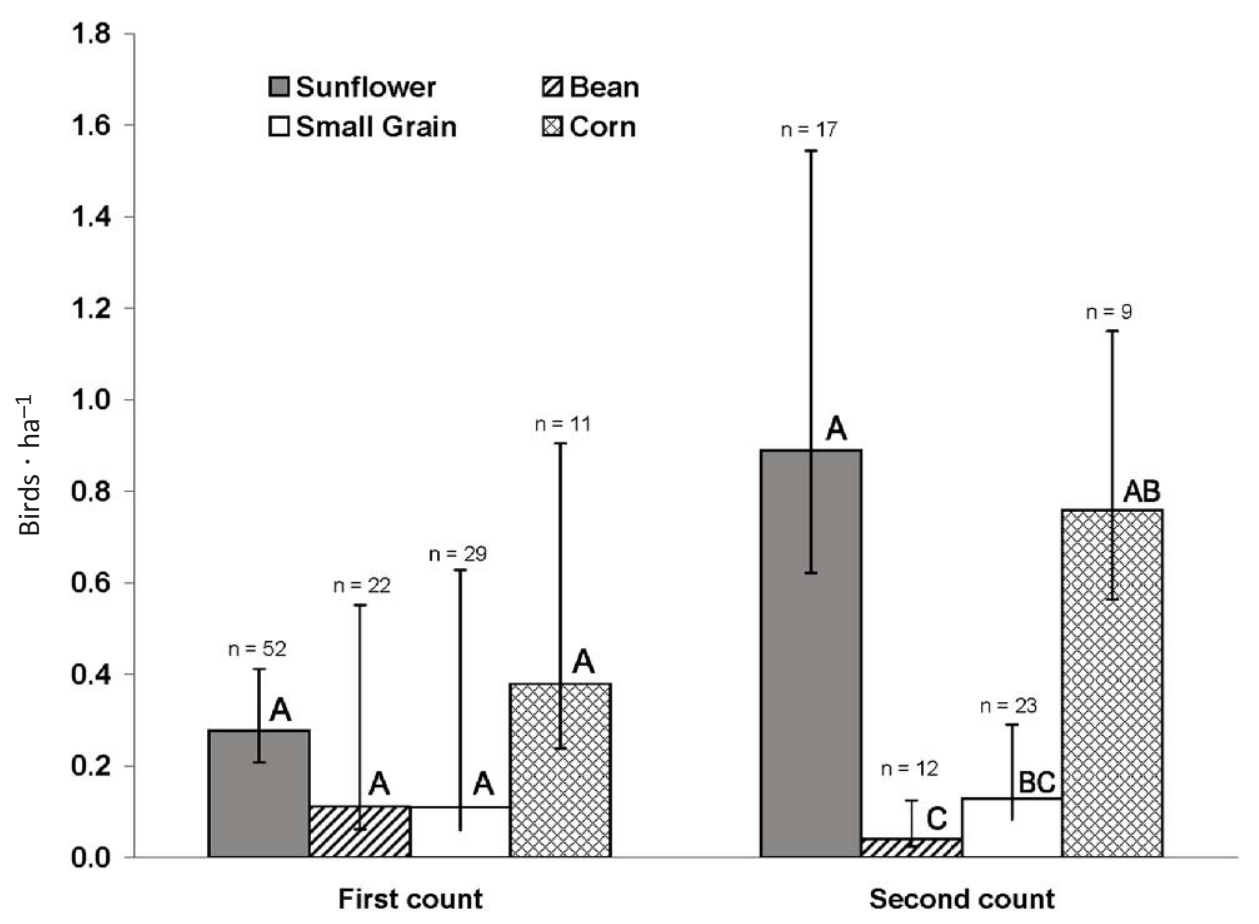

Fig. 2. Mean densities and associated standard errors of blackbirds (birds $\cdot \mathrm{ha}^{-1}$ ) in harvested sunflower, bean, small grain, and corn fields in the Southern Drift Plains, North Dakota, 2003 and 2004. Crops with different letters are significantly different at $\alpha=0.05$. Data were back-transformed from natural-log transformations by raising 10 to the power of the mean species per hectare.

Lapland Longspurs/Horned Larks made up $60 \%$ of the birds counted during our study. Lapland Longspur/Horned Lark densities differed $(F=5.08, P=0.026)$ between the first count $\left(\bar{x}=2.74, s_{\bar{x}}=0.43\right)$ and second count $\left(\bar{x}=0.80, s_{\bar{x}}=0.43\right)$. During the first count, Lapland Longspur/Horned Lark densities differed among the 4 crops $(F=11.68, P<$ 0.001 ), with sunflower hosting a greater density of birds than did corn, soybean, and small grain (Fig. 3). During the second count, their densities did not differ among crop types $(F=$ 1.61, $P=0.199$ ), with most migrating out of the study area prior to the second count. Lapland Longspur/Horned Lark densities did not differ between untilled and tilled fields during the first $(t=1.72, P=0.089)$ or second counts $(t=0.40, P=0.691)$.

Other bird species were relatively rare and thus were not subjected to inferential statistical analyses. When waterfowl were encountered, they were seen either in pairs or in large flocks and usually near wet areas. Most sparrows and gallinaceous birds were seen near vegetation along edges of fields and wetlands.

\section{Discussion}

We found that species richness and bird densities were greater in harvested corn and sunflower fields than in harvested small grain and soybean fields, with soybean fields harboring the fewest species and lowest bird density. These differences might be partially related to the energy value of each seed crop, which is highest in sunflower $\left(27 \mathrm{~kJ} \cdot \mathrm{g}^{-1}\right)$, followed by soybean $\left(22 \mathrm{~kJ} \cdot \mathrm{g}^{-1}\right)$, corn $(18.5 \mathrm{~kJ}$. $\left.\mathrm{g}^{-1}\right)$, and small grain $\left(16 \mathrm{~kJ} \cdot \mathrm{g}^{-1}\right)$ (Kendeigh and West 1965, Warner et al. 1989, Diaz 1990). However, while soybeans do have a higher energy value than corn, they also have digestion inhibitors that can decrease a bird's appetite and result in weight loss (Dabbert and Martin 1994). Lastly, soybeans are harvested close to the ground, which leaves very few alternate food sources or little standing crop residue for protective cover. In contrast, corn stubble provides considerable vertical dimension, and the waste kernels are highly palatable grains, even for relatively small-sized passerines, because the kernels absorb soil 


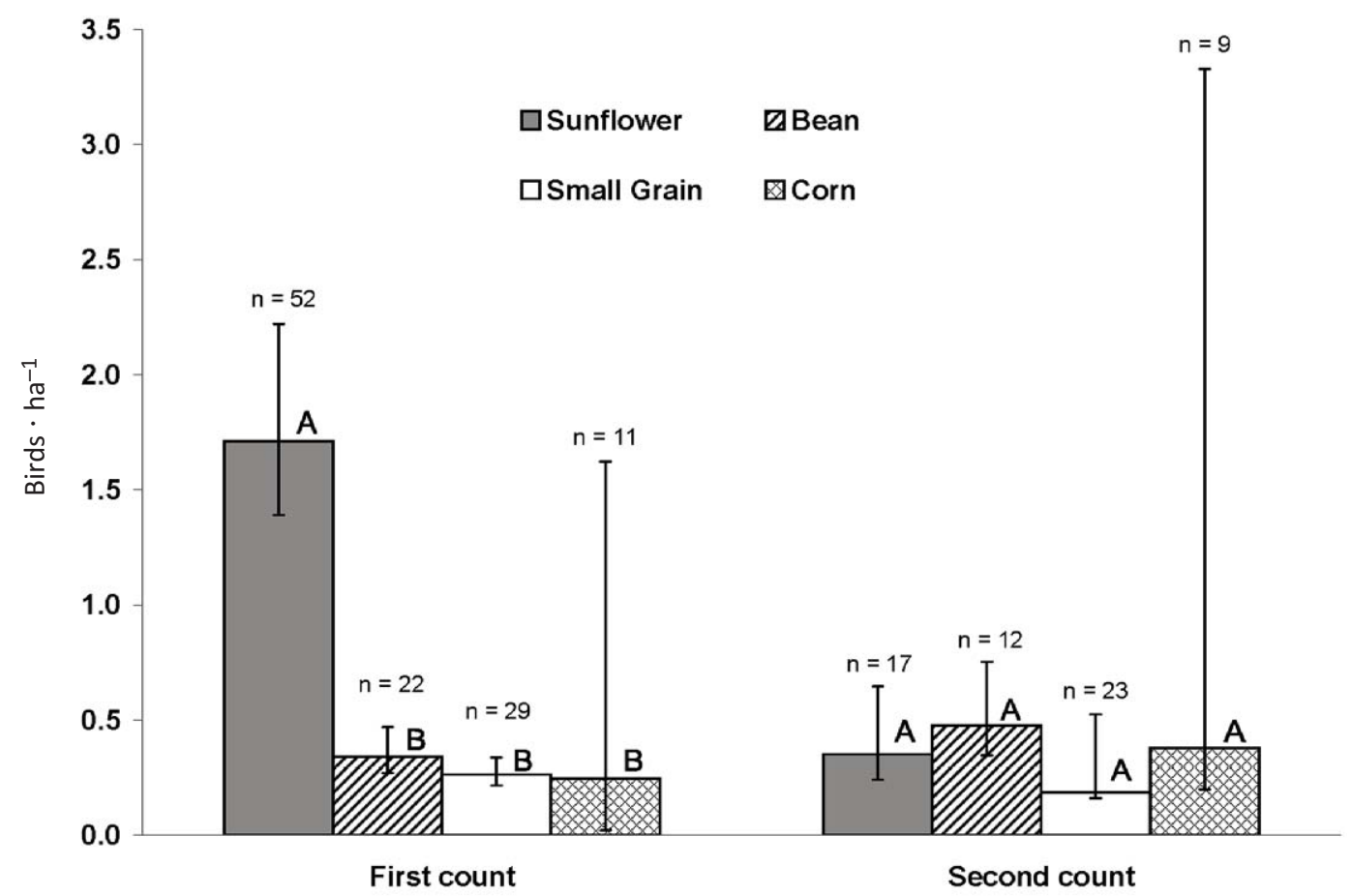

Fig. 3. Mean densities and associated standard errors of Horned Larks/Lapland longspurs (birds $\cdot \mathrm{ha}^{-1}$ ) in sunflower, bean, small grain, and corn fields throughout the Southern Drift Plains, North Dakota, 2003 and 2004. Crops with different letters are significantly different at $\alpha=0.05$. Data were back-transformed from natural-log transformations by raising 10 to the power of the mean species per hectare.

moisture and soften considerably. These factors may account for the large numbers of birds that were found in cornfields. Currently, sunflower fields are not as prevalent as cornfields in the PPR, but sunflower's high energy value, and perhaps passerines' prior experience with foraging on ripening sunflower in the fall, attracted passerines to this crop (Linz et al. 1984, Schaaf et al. 2008). Although some stubble is maintained in smallgrain fields after harvest, providing the necessary cover for birds, small-grain seeds have a comparatively lower energy value than the other crop types. This may account for the low use of harvested small-grain fields.

The development of broad-spectrum herbicides for soybeans and corn has made weed control cost-effective for both crops (Krapu et al. 2004). In contrast, herbicides developed for sunflower are less robust, sometimes leading to poor weed control and to formation of dense patches of weeds within fields. These patches can provide cover for birds while also allowing them to forage on weed seeds and waste sunflower (Linz et al. 1984). Mature weeds leave behind a store of seeds that can be of value to foraging birds (Wilson et al. 1996). For example, seed production of foxtail species common to the Northern Great Plains (e.g., Setaria viridis and S. glauca) is prolific. For S. viridis found growing in corn and soybean fields and not treated with postemergent herbicide, seed production was about 4000 seeds $\cdot \mathrm{m}^{-2}$ (Forcella et al. 2001). Seed density declined to about 400 seeds $\cdot \mathrm{m}^{-2}$ when postemergent herbicide was applied early in the growing season. While the stubble of small grains can contain weed seeds and waste grains, it lacks substantial cover compared to that of either sunflower or corn with their vertical structure.

Our data showed that untilled fields tended to support a greater density of foraging birds than fields tilled the previous fall. In tilled fields, the overturned soil hides waste grains, weed seeds, and arthropods that otherwise would be available to foraging birds (Castrale 1985, Warner et al. 1985, Koford and Best 
1996, Hesler and Berg 2003). The amount of waste grains and seeds hidden through tilling is significant. Wastage from harvesting sunflower can range from $3 \%$ to $20 \%$ of total yield (Hofman and Hellevang 1997). In cornfields, Warner et al. (1989) found that between 247 and $446 \mathrm{~kg} \cdot \mathrm{ha}^{-1}$ of corn kernels were left after harvest, and between 142 and $214 \mathrm{~kg}$. $\mathrm{ha}^{-1}$ of soybeans were left. Losses before and during harvest include (1) natural losses caused by weather conditions and animal contact, (2) harvesting losses as the crop enters the machine, and (3) combine threshing and separating losses.

Although the amount of waste is substantial, spring migrants may not always benefit from it. Waste availability decreases from fall through early spring (Robel and Slade 1965, Warner et al. 1989, Wilson and Aebischer 1995). Late-season migrants or resident birds feed steadily in harvested fields throughout fall and winter, causing a decline in seed density, especially near cover (Robinson and Sutherland 1999). In extreme cases, near large roosts of blackbirds for example, nearly all of the wastage may be taken from fields. Waste corn was measured at 69 kernels $\cdot \mathrm{m}^{-2}$ in corn stubble near a blackbird roost during November; by February, density had dropped to $<3$ kernels $\mathrm{m}^{-2}$ (Dolbeer et al. 1978). It is unlikely that harvested cornfields in the PPR would receive that kind of pressure, but certainly blackbirds numbering in the hundreds-of-thousands at fall roosts could remove large amounts of waste foods from harvested fields in the PPR. Foods might be available in other, less-preferred habitats (such as small grain) but lack of adequate cover may prevent foraging in these areas (Castrale 1985).

\section{MANAGEMENT IMPLICATIONS}

Ultimately, nutritional acquisition during spring migration could determine reproductive success on breeding grounds (Rappole and Warner 1976, Weatherhead and Bider 1979, Smith and Moore 2005). We agree with others (e.g., Moore et al. 1995, Holmes 2007) that efforts to preserve breeding grounds will fall short of conservation goals if quality stopover habitats en route are not provided. The possibility that interseasonal habitat quality affects productivity of breeding birds seems reasonable and warrants further investigation
(Holmes 2007). Our data support the notion that harvested agricultural fields in the PPR are important stopover habitats for granivorous spring-migrating birds. Furthermore, it appears that leaving stubble in untilled grain fields provides preferred foraging patches needed by a variety of migratory birds (Wilson et al. 1996). Linking the effects of reduced availabilities of food and cover in harvested fields during spring migration to subsequent reproductive effort is difficult to quantify because of the technological difficulty of tracking individual birds over seasons. We speculate that some bird populations in the Northern Great Plains could be positively affected by continued planting of row crops with postharvest vertical structure (e.g., sunflower and corn) and use of no-till practices. By leaving crop residue in the fields through conservation practices or reduced tillage, the availability of food and cover for wildlife may be extended through spring migration (Gremaud 1983, Warner et al. 1989, Lokemoen and Beiser 1997).

\section{ACKNOWLEDGMENTS}

D. Schaaf, F. Chan, and H. Langord assisted with data gathering. J. Church and G. Forcey provided help with GIS and statistical analysis. This project was supported by the Department of Biological Sciences at North Dakota State University, Fargo; the National Sunflower Association, Bismarck, North Dakota; and the U.S. Department of Agriculture's North Dakota/South Dakota Wildlife Services and National Wildlife Research Center.

\section{Literature Cited}

BEASON, R.C. 1995. Horned Lark (Eremophila alpestris). Number 195 in A. Poole, P. Stettenheim, and F. Gill, editors, The birds of North America. Academy of Natural Sciences, Philadelphia, PA, and American Ornithologists' Union, Washington, DC.

Best, L.B., H. Campa, III, K.E. Kemp, R.J. Robel, M.R. Ryan, J.A. SAVIDGE, H.P. WeEks, JR., AND S.R. WiNTERSTEIn. 1998. Avian density in CRP and crop fields during winter in the Midwest. American Midland Naturalist 139:311-324.

Castrale, J.S. 1985. Responses of wildlife to various tillage conditions. Transactions of the North American Wildlife and Natural Resources Conference 50: $142-256$.

CoDy, M.L. 1985. An introduction to habitat selection in birds. Pages 3-56 in M.L. Cody, editor, Habitat selection in birds. Academic Press, Inc., Orlando, FL. 
Dabbert, C.B., and T.E. Martin. 1994. Effects of diet composition and temperature on food choice of captive mallards. Southwestern Naturalist 39:143-147.

DiAZ, M. 1990. Interspecific pattern of seed selection among granivorous passerines: effects of seed size, seed nutritive value and bird morphology. Ibis 32:467-476.

Dolbeer, R.A., P.P. Woronecki, A.R. STICKLEY, JR., AND S.B. White. 1978. Agricultural impacts of a winter population of blackbirds and starlings. Wilson Bulletin 90:31-44.

Forcella, F., N. Colbach, and G.O. Kegode. 2001. Estimating seed production of three Setaria species in row crops. Weed Science 48:436-444.

Gremaud, G.K. 1983. Factors influencing nongame bird use of rowcrop fields. Master's thesis, Iowa State University, Ames.

Hanowski, J.M., G.J. Niemi, and J.G. Blake. 1990. Statistical perspectives and experimental design when counting birds on line transects. Condor 92:326-335.

Hesler, L.S., AND R.K. BERG. 2003. Tillage impacts cereal-aphid (Homoptera: Aphididae) infestations in spring small grains. Journal of Economic Entomology 96:1792-1797.

Hofman, V.L., and K.J. Hellevang. 1997. Harvesting, drying and storage of sunflower. Pages 671-696 in A.A. Schneiter, editor, Sunflower technology and production. American Society of Agronomy, Inc., Crop Science Society of America, Inc., Soil Science Society of America, Inc., Madison, WI.

Holmes, R.T. 2007. Understanding population change in migratory songbirds: long-term and experimental studies of Neotropical migrants in breeding and wintering areas. Ibis 149:2-13.

Hussell, D.J.T., and R. Montgomerie. 2002. Lapland Longspur (Calcarius lapponicus). Number 656 in A. Poole and F. Gill, editors, The birds of North America, Inc., Philadelphia, PA.

HutTo, R.L. 1998. On the importance of stopover sites to migrating birds. Auk 115:823-825.

2000. On the importance of en route periods to the conservation of migratory landbirds. Studies in Avian Biology 20:109-114.

IGL, L.D., AND B.M. BALLARD. 1999. Habitat associations of migrating and overwintering grassland birds in southern Texas. Condor 101:771-782.

IGL, L.D., AND D.H. JoHnson. 1997. Changes in breeding bird populations in North Dakota: 1967 to 1992-93. Auk 114:74-92.

Kelly, J.F., L.S. Delay, and D.M. Finch. 2002. Densitydependent mass gain by Wilson's Warblers during stopover. Auk 119:210-213.

Kendeigh, S.C., AND G.C. WEST. 1965. Caloric values of plant seeds eaten by birds. Ecology 46:553-555.

Klute, D.S., AND R.J. RobEL. 1997. Seed availability in grazed pastures and Conservation Reserve Program fields during winter in Kansas. Journal of Field Ornithology 68:253-258.

Koford, R.R., AND L.B. Best. 1996. Management of agricultural landscapes for the conservation of Neotropical migratory birds. Pages 68-88 in F.R. Thompson, III, editor, Management of agricultural landscapes for the conservation of neotropical migratory birds. General Technical Report NC-187, USDA Forest Service, North Central Forest Experiment Station, St. Paul, MN

Krapu, G.L., D.A. Brandt, and R.R. Cox, Jr. 2004. Less waste corn, more land in soybeans, and the switch to
GM crops: trends with important implications to wildlife management. Wildlife Society Bulletin 32 127-136.

LinZ, G.M., D.L. VAKOCH, J.F. Cassel, and R.B. CARLSON. 1984. Food of red-winged blackbirds (Agelaius phoeniceus) in sunflower fields and corn fields. Canadian Field-Naturalist 98:38-44.

Lokemoen, J.T., AND J.A. Beiser. 1997. Bird use and nesting in conventional, minimum-tillage, and organic cropland. Journal of Wildlife Management 61:44-655.

MaLone, C.R. 1967. A rapid method for enumeration of viable seeds in soil. Weeds 15:381-382.

Marcum, C.L., and D.O. Loftsgaarden. 1980. A nonmapping technique for studying habitat preferences. Journal of Wildlife Management 44:963-968.

Moorcroft, D., M.J. Whittingham, R.B. Bradbury, and J.D. WILSON. 2002. The selection of stubble fields by wintering granivorous birds reflects vegetation cover and food abundance. Journal of Applied Ecology 39: $535-547$.

Moore, F.R., S.S. Gauthreaux, Jr., P. Derlinger, and T.R. SimONS. 1995. Habitat requirements during migration: important link in conservation. Pages 121-144 in T.E. Martin and D.M. Finch, editors, Ecology and management of neotropical migratory birds. Oxford University Press, Inc., New York.

[NRCS] Natural Resources Conservation Service, USDA. 2004. Data Gateway: Digital Ortho Quad Mosaic by AFPO. Available from: http://datagateway .crcs.usda.gov/GatewayHome.html [cited 24 August 2004; accessed 17 November 2009].

[NDASS] North Dakota Agricultural Statistics SERVICE, USDA. 2005. North Dakota Agricultural Statistics 2004. North Dakota State University, Fargo.

Perkins, A.J., M.J. Whittingham, R.B. Bradbury, J.D. Wilson, A.J. Morris, and P.R. Barnett. 2000. Habitat characteristics affecting use of lowland agricultural grassland birds in winter. Biological Conservation 95:279-294.

Peterjohn, B.G. 2003. Agricultural landscapes: can they support healthy bird populations as well as farm products? Auk 120:14-19.

Petit, D.R. 2000. Habitat use by landbirds along Nearctic-neotropical migration routes: implications for conservation of stopover habitats. Studies in Avian Biology 20:15-33.

Pravosudov, V.V., E.C. Grubb, Jr., R.F. Doherty, Jr., C.L. Bronson, E.V. Pravosudov, and A.S. Dolby. 1999. Social dominance and energy reserves in wintering woodland birds. Condor 101:880-884.

Rappole, J.H., AND D.W. Warner. 1976. Relationships between behavior, physiology and weather in avian transients at a migration stopover site. Oecologia 26:193-212

Robel, R.J., and N.A. Slade. 1965. The availability of sunflower and ragweed seeds during fall and winter. Journal of Wildlife Management 29:202-206.

Robinson, R.A., AND W.J. SutherLand. 1999. The winter distribution of seed-eating birds: habitat structure, seed density and seasonal depletion. Ecography 22 : $447-454$.

Rodewald, P.G., AND M.C. Brittingham. 2002. Habitat use and behavior of mixed species landbird flocks during fall migration. Wilson Bulletin 114:87-98.

Russell, R.W., F.L. Carpenter, M.A. Hixon, and D.C. PATON. 1994. The impact of variation in stopover 
habitat quality on migrant Rufous Hummingbirds. Conservation Biology 8:483-490.

Sawin, R.S., G.M. Linz, W.J. Bleier, and H.J. Homan. 2006. Feeding habitats of spring-migrating blackbirds in east-central South Dakota. Prairie Naturalist 38:74-84.

SchaAf, D.A., G.M. Linz, C. Doetkott, M.W. Lutman, AND W.J. BLEIER. 2008. Non-blackbird avian occurrence and abundance in North Dakota sunflower fields. Prairie Naturalist 40:73-86.

Schaub, M., And L. Jenni. 2001. Variation of fuelling rates among sites, days and individuals in migrating passerine birds. Functional Ecology 15:584-594.

Smith, R.J., AND F.R. Moore. 2005. Fat stores of American Redstarts (Setophaga ruticilla) arriving at northerly breeding grounds. Journal of Avian Biology 36:117-126.

STEwaRT, R. 1975. Breeding birds of North Dakota. TriCollege Center for Environmental Studies, Fargo, ND.

Stewart, R., and H.A. Kantrud. 1972. Population estimates of breeding birds in North Dakota. Auk 89:766-788.

Tankersley, R., JR., and K. Orvis. 2003. Modeling the geography of migratory pathways and stopover habitats for neotropical migratory birds. Conservation Ecology 7:7-22.
Warner, R.E., S.P. Havera, and L.M. David. 1985. Effects of autumn tillage systems on corn and soybean harvest residues in Illinois. Journal of Wildlife Management 49:185-190.

Warner, R.E., S.P. Havera, L.M. David, and R.J. Siemers. 1989. Seasonal abundance of waste corn and soybeans in Illinois. Journal of Wildlife Management 53:142-148.

Watkinson, A.R., R.P. Freckleton, R.A. Robinson, AND W.J. SutherLand. 2000. Predictions of biodiversity response to genetically modified herbicide-tolerant crops. Science 289:1554-1557.

Weatherhead, P.J., And J.R. Bider. 1979. Management options for blackbird problems in agriculture. Phytoprotection 60:145-155.

Wilson, J.D., R. TaYlor, and L.B. Muirhead. 1996. Field use by farmland birds in winter: an analysis of field type preferences using resampling methods. Bird Study 43:320-332.

Wilson, P.J., AND N.J. Aebischer. 1995. The distribution of arable weeds in relation to distance from the field edge. Journal of Applied Ecology 32:295-310.

Received 2 April 2008 Accepted 9 June 2009 